
inbred lines of Habanero pepper to Ralstonia pseudosolanacearum and Phytophthora capsici. Horticultura Brasileira, 37: 395-401. DOI - http://dx.doi. org/10.1590/S0102-053620190406

\title{
Reaction of advanced inbred lines of Habanero pepper to Ralstonia pseudosolanacearum and Phytophthora capsici
}

\author{
Renato S Soares ${ }^{1} \mathbb{D}$; Cláudia SC Ribeiro ${ }^{2} \mathbb{D}$; Carlos F Ragassi ${ }^{2} \mathbb{D}$; Carlos A Lopes ${ }^{2} \mathbb{D}$; Sabrina IC Carvalho

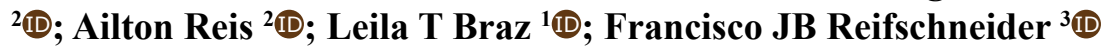

${ }^{1}$ Universidade Estadual Paulista (UNESP), Faculdade de Ciências Agrárias e Veterinárias, Jaboticabal-SP, Brasil; renato.silva070@gmail. com, leila.braz@unesp.br; ${ }^{2} E m b r a p a$ Hortaliças, Brasília-DF, Brasil; claudia.ribeiro@embrapa.br; carlos.ragassi@embrapa.br; carlos. lopes@embrapa.br; sabrina.carvalho@embrapa.br; ailton.reis@embrapa.br; ${ }^{3}$ Embrapa, Secretaria de Inteligência e Relações Estratégicas, Brasília-DF, Brasil; francisco.reifschneider@embrapa.br.

\begin{abstract}
Habanero pepper is important in the international market and is becoming popular in the national market; however, few cultivars adapted and resistant to devastating diseases caused by the soilborne pathogens Ralstonia pseudosolanacearum (RP) and Phytophthora capsici (PC) are available in Brazil. The aim of this study was to evaluate the reaction of Habanero-type advanced inbred lines, developed by Embrapa Hortaliças breeding program, to RP and PC. Although not required for the process of protection, registration and release of new cultivars, this information is important. CNPH 15.737; CNPH 15.740; CNPH 15.744; CNPH 15.745; CNPH 15.749 and CNPH 15.750 were inoculated with three RP and one PC isolates. Plants showing wilted leaves (RP) and stem necrosis, leaf wilting and damping off (PC) were quantified. Total area under the disease progress curve (AUDPC) was obtained using incidence values and also severity index for RP. CNPH 15.740 and CNPH 15.737 were highly resistant to RP. CNPH 15.749 displayed considerable resistance levels to PC. CNPH 15.740 showed high resistance to $\mathrm{RP}$ isolates and intermediate resistance to $\mathrm{PC}$ isolates which also shows agronomic traits of interest to the sector, therefore with a high potential to be released as a new cultivar.
\end{abstract}

Keywords: Capsicum, bacterial wilt, Phytophthora wilt, incidence, severity index, resistance.

\section{RESUMO}

Reação de linhagens avançadas de pimenta Habanero a Ralstonia pseudosolanacearum e Phytophthora capsici

A pimenta Habanero é popular no mercado internacional e começa a despertar maior interesse no nacional, porém poucas cultivares adaptadas às condições edafoclimáticas e com resistência às principais doenças como murcha bacteriana (MB) e murcha de fitóftora (MF), causadas respectivamente por Ralstonia pseudosolanacearum (RP) e Phytophthora capsici (PC), estão disponíveis no Brasil. O objetivo deste estudo foi avaliar a reação de linhagens avançadas de pimenta do grupo Habanero desenvolvidas pelo programa de melhoramento da Embrapa Hortaliças à MB e MF. Apesar de não ser exigida no processo de registro, proteção e lançamento de novas cultivares, esta informação é importante para os produtores. As linhagens avançadas identificadas como CNPH 15.737, CNPH 15.740, CNPH 15.744, CNPH 15.745, CNPH 15.749 e CNPH 15.750 foram inoculadas com três isolados de RP e um de PC. Quantificaram-se as plantas com folhas murchas (RP) e com necrose do caule, murcha das folhas e tombamento para PC. A área total abaixo da curva de progresso da doença (AACPD) foi obtida utilizando-se valores de incidência e, também, o índice de severidade para RP. CNPH 15.740 e CNPH 15.737 apresentaram alta resistência a RP. CNPH 15.749 apresentou nível moderado de resistência à PC. Merece destaque especial a linhagem CNPH 15.740, com nível elevado de resistência aos isolados de RP e intermediário a PC e que também possui características agronômicas desejáveis tendo, portanto, alto potencial como nova cultivar a ser disponibilizada aos produtores.

Palavras-chave: Capsicum, murcha bacteriana, murcha de fitóftora, incidência, índice de severidade, resistência.

Received on July 29, 2019; accepted on October 2, 2019

$\mathrm{H}^{2}$ abanero is a highly diversified pepper group belonging to the species Capsicum chinense. Fruits can present different pungency levels, sizes and colors (Castro-Concha et al., 2014). This group of pepper is mainly cultivated in tropical and subtropical regions (Teodoro et al., 2013), especially in the region of Yucatán, in Mexico (Bosland \& Coon, 2015), where productivity can reach $40 \mathrm{t} \mathrm{ha}^{-1}$ (Vázquez \& Cortez, 2018).

Although originated in the Amazon basin, Habanero pepper is still little known in Brazil (Ribeiro et al., 2015). However, interest on this pepper group has been increasing at both national and international levels for the sauce and mash markets. This is due mainly to its unique flavor and aroma, besides generally high pungency levels (Nass et al., 2015). Few Habanero-type cultivars are registered and adapted to Brazilian conditions. Thus, it is essential 
to develop new cultivars adapted to Brazilian conditions, showing traits of interest such as pungency, outstanding flavor, strong aroma and high yield, as well as resistance to its main pathogens.

Among the pathogens that attack pepper plants (Capsicum spp.), stand out those that are soilborne and cause direct damages to the root system and to the stem base, consequently affecting the vegetative development and fruit production (Naresh et al., 2019). The main soilborne pathogens of pepper plants reported are Ralstonia pseudosolanacearum sp. (RP; Lebeau et al., 2011; Granke et al., 2012; Rossato et al., 2018), Phytophthora capsici (PC; Gilardi et al., 2013; Reeves et al., 2013; Sánchez-Chávez et al., 2017), presented in this study, and Meloidogyne nematodes (Pinheiro et al., 2014), which cause bacterial wilt, phytophthora blight and root knot, respectively.

The bacterium Ralstonia pesudosolanacearum originates from the recent taxonomic reorganization of $R$. solanacearum, previously identified as race 1 biovar 3 , phylotype I (Rossato et al., 2018). This species is more aggressive than $R$. solanacearum (races 1, 2, 3, biovars 1, 2, phylotype II) on Capsicum, and presents higher evolution rates and the largest geographical distribution worldwide (Lopes \& Boiteux, 2004; Rossato et al., 2018). This fact was also noticed under natural conditions in the Amazon region (Coelho Netto et al., 2004). The bacterium penetrates the root system and proliferates in the xylem, causing irreversible wilting and, consequently, plant death (Lebeau et al., 2011). Hong et al. (2012) reported that bacterial wilt affects solanaceous yield in over 80 countries, with annual losses of more than one billion dollars.

The oomycete Phytophthora capsici is found in practically all solanaceousproducing regions of the world and is considered one of the most destructive soilborne pathogens of Capsicum peppers (Sánchez-Chávez et al., 2017). This phytopathogen causes root rot and stem base rot, leading to sudden wilting, dark brown necrosis of stem base and plant death (Dunn et al., 2014). The variability of the species is represented by more than 45 physiological races (Barchenger et al., 2018). In Brazil, Ribeiro \& Bosland (2012) identified eight physiological races of $P$. capsici in sweet pepper areas, and race 18 was the most common in the Central region. $P$. capsici reproduces both sexually and asexually, being characterized as a persistent problem, especially after consecutive cultivations of susceptible host plants (Naresh et al., 2019). Its establishment and propagation are favored by excessive humidity, poor drainage and high soil temperature (Granke et al., 2012; Petry et al., 2016).

The use of resistant cultivars is considered the best management strategy to control diseases caused by $R$. pseudosolanacearum and $P$. capsici (Naresh et al., 2019). Resistant cultivars are attractive since they are easy to be adopted by farmers and result in less environmental impacts than any other disease control strategy (Granke et al., 2012). Sources of resistance to these two diseases were identified in accessions of Capsicum spp. (Madeira et al., 2016; Petry et al., 2016, Rossato et al., 2018). Currently, the hybrid rootstock BRS Acará developed by Embrapa Hortaliças, has shown multiple resistance to several isolates of $P$. capsici and $R$. pseudosolanacearum, besides Meloidogyne incognita (Madeira et al., 2016).

Little emphasis has been given to developing disease resistant cultivars of Capsicum spp., such as C. baccatum, $C$. frutescens and C. chinense. Embrapa Hortaliças' Capsicum breeding program aims to develop Habanero pepper genotypes resistant to $P$. capsici and $R$. pseudosolanacearum, as well as to other pathogens which attack the crop, besides attributes such as high yield, nutritional quality, and adaptation to tropical growing conditions. In this breeding program, six new advanced inbred lines $\left(\mathrm{S}_{5}\right)$, from a base population of Habanero pepper with a wide genetic variability (Nass et al., 2015) were obtained after generations of selection using selfpollination methodology and individual plant selection with progeny test. These inbred lines are in the evaluation step for cultivar registration and protection of cultivars, mandatory by Brazilian legislation.

The aim of this study was to evaluate the reaction of six advanced inbred lines of Habanero pepper from Embrapa Hortaliças' breeding program to $R$. pseudosolanacearum and $P$. capsici. Although not required, this information is important as additional data in the process of protection, registration and release of new cultivars.

\section{MATERIAL AND METHODS}

\section{Genotypes and pathogens}

Advanced inbred lines of Habanero pepper CNPH 15.737, CNPH 15.740, CNPH 15.744, CNPH 15.745, CNPH 15.749 and CNPH 15.750 (Table 1), from Embrapa Hortaliças' breeding program, were evaluated for reaction to $R$. pseudosolanacearum and $P$. capsici. Two experiments were carried out in a greenhouse of Embrapa Hortaliças, located in Brasília, Distrito Federal, Brazil, (15'55'60' 'W and $48^{\circ} 08^{\prime} 34^{\prime}$ 'S, altitude $990 \mathrm{~m}$ ), from November to December, 2018 ( $P$. capsici) and from April to May, 2019 (R. pseudosolanacearum).

Reaction to inoculation with $\boldsymbol{R}$. pseudosolanacearum isolates

The reaction of the six Habanero inbred lines to $R$. pseudosolanacearum was compared with two $C$. annuum genotypes used as control, CNPH 143 (resistant) and Tico (susceptible). Inbred lines and controls were sown in expanded polystyrene trays filled with sterile commercial substrate Carolina Soil ${ }^{\circledR}$ and kept in the greenhouse until inoculation and transplanting.

$R$. pseudosolanacearum isolates CNPH RS476, CNPH RS634 and CNPH RS639 were used in the inoculation. They were previously selected from the phytopathogenic bacteria collection of Embrapa Hortaliças for being highly virulent to pepper plants, as well as for the geographical diversity among isolates. These isolates were collected in different regions of Brazil, in Dom Pedro-MA, Guadalupe-PI and Altamira$\mathrm{PA}$, respectively. Inocula were prepared using the methodology described by Rossato et al. (2018). 
At 45 days after sowing (DAS), seedlings of inbred lines and control genotypes were inoculated with the three $R$. pseudosolanacearum isolates, separately, by spraying $5 \mathrm{~mL}$ of a bacterial suspension, containing

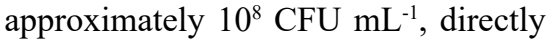
on each plant root system exposed after removal from the tray (Lopes \& Boiteux, 2004). After inoculation, the plants were transplanted to 1-liter plastic pots containing sterile soil and kept in a greenhouse during 27 days with night heating, preventing temperature drop below $20^{\circ} \mathrm{C}$, which could increase the chance of escape. The temperature observed during the experimental period was $30 \pm 10^{\circ} \mathrm{C}$.

Disease incidence was evaluated every three days. The evaluation started when the early symptoms appeared in the susceptible control [nine days after inoculation (DAI)]. Plants which presented wilting or the ones which died were counted, totalizing eight evaluations during the crop cycle $(6,9$, 12, 15, 18, 21, 24 and 27 DAI), always in the afternoon in order to uniform the analysis. The last evaluation (at $27 \mathrm{DAI}$ ) occurred when the number of wilted plants stabilized.

Values of average disease incidence of each plot were used to calculate area under the disease progress curve (AUDPC) (Shaner \& Finney, 1977). Disease severity was also evaluated at 26 DAI using a note scale from 1 to 5 (Winstead \& Kelman, 1952), in which the lowest note corresponded to lack of wilting and the highest note to plant death. Notes 3 and above were attributed to plants which showed irreversible symptoms of wilting (susceptible) and notes between 1.5 to 2.5 were attributed to plants which showed light wilting symptoms, reversible after irrigation or at the coolest hours of the day.

A randomized complete block design, in factorial scheme $8 \times 3$ (six advanced inbred lines of Habanero and two controls CNPH 143 and Tico, and three $R$. pseudosolanacearum isolates), with four replicates, were used. Plots were composed of six plants, with two plants per pot.

Reaction to inoculation with $\boldsymbol{P}$. capsici (isolate Pcp116, race 18)
Reactions of the six advanced Habanero lines to $P$. capsici were compared to those of $C$. annuum controls CNPH 148 (resistant) and bell pepper cultivar Ikeda (susceptible). Seedlings of inbred lines and control genotypes were produced according to what was described for the $R$. pseudosolanacearum experiment. At 45 DAS, seedlings were transplanted to 3-L plastic pots containing sterile soil. The base of each plant received $3 \mathrm{~mL}$ of a solution containing a suspension of $2 \times 10^{4}$ zoospores $/ \mathrm{mL}^{-1}$ of the Pcp 116 isolate, two days after transplant. The isolate was collected in the state of Goiás in 2007 and selected because of its high virulence. Inoculum was prepared based on the methodology described by Petry et al. (2016).

The experimental design was completely randomized, with eight treatments (inbred lines and controls) and five replications, three plants per experimental plot, totalizing 15 plants/ treatment.

Assessment of disease incidence began at six DAI when first wilted plants of susceptible control (cultivar Ikeda) were observed. The evaluation was repeated every two days, totalizing six readings during the crop cycle. The incidence was evaluated using the quantity of plants with wilting symptoms, damping off and stem base necrosis in each experimental plot. The values of the average incidence of each plot were used to calculate the AUDPC (Shaner \& Finney, 1977).

\section{Statistical analysis}

Variance of severity caused by RP and AUDPC for RP and PC were estimated. Homogeneity and normality of residue of the mathematical model were tested, using Bartlett (Steel et al., 1997) and Jarque-Bera (1987) tests, respectively. ANOVA with F test was carried out and the means among treatments were compared by Tukey test. In all statistical analyses, $\mathrm{p}<0.05$ was adopted. Statistical analyses were carried out using SISVAR v.5.6 statistical software (Ferreira, 2011), as well as Pearson correlation for AUDPC values and severity caused by RP.

\section{RESULTS AND DISCUSSION}

\section{Reaction of inbred lines to $R$. pseudosolanacearum}

Significant effect among Habanero pepper lines and $R$. pseudosolanacearum isolates was detected for both AUDPC and a single reading of disease severity at 26 DAI. There was significance for interaction between genotypes and isolates for both evaluations. Significant correlation was also observed between AUDPC and severity, with $\mathrm{R}^{2}$ values for CNPH RS476, CNPH RS634 and CNPH RS639 isolates of $0.80 ; 0.87$ and 0.88 , respectively. Thus, it is possible to state that AUDPC and severity were highly associated parameters.

Inoculation was successful for all RP isolates and environmental conditions were favorable for disease development, allowing the differentiation of incidence and resistance classes among genotypes. The disease progressed rapidly in the susceptible control, as expected, showing first wilting symptoms at five DAI. The standard resistance control, CNPH 143, was asymptomatic to all isolates, as previously observed by

Table 1. Main plant and fruit traits of six Habanero pepper lines. Brasília, Embrapa Hortaliças, 2019.

\begin{tabular}{lccccc}
\hline Inbred lines & $\begin{array}{c}\text { Plant } \\
\text { architecture }\end{array}$ & Fruit shape & $\begin{array}{c}\text { Fruit } \\
\text { color }\end{array}$ & Pungency & Aroma \\
\hline CNPH 15.737 & Intermediate & Campanulated & Red & High & Medium \\
CNPH 15.740 & Intermediate & Campanulated & Red & High & Medium \\
CNPH 15.744 & Upright & Rectangular & Yellow & Low & Strong \\
CNPH 15.745 & Intermediate & Campanulated & Red & Intermediate & Weak \\
CNPH 15.749 & Intermediate & Campanulated & Red & Very high & Medium \\
CNPH 15.750 & Intermediate & Campanulated & Red & Very High & Medium \\
\hline
\end{tabular}


Lopes \& Boiteux (2004).

$\mathrm{CNPH} 15.737$ and $\mathrm{CNPH} 15.740$ displayed the lowest incidence, AUDPC and severity, in average values, for the three $R$. pseudosolanacearum isolates, differing significantly from the susceptible control (Figure 1, Table 2). CNPH 15.740 did not show wilted plants during the experiment when inoculated with isolate CNPH RS476. CNPH 15.737; CNPH 15.740 and CNPH 15.744 were highly resistant to isolate CNPH RS476, not differing significantly from the resistant control CNPH 143 for all evaluations (Figure 1, Table 2). High resistance of inbred lines CNPH 15.737; CNPH 15.740 and CNPH 15.744 was also observed for isolate CNPH RS639, for the variables AUDPC and severity (Table 2). CNPH 15.737 did not differ significantly from CNPH 143 in severity when inoculated with isolate CNPH RS634. Although the inbred line CNPH 15.740 differed

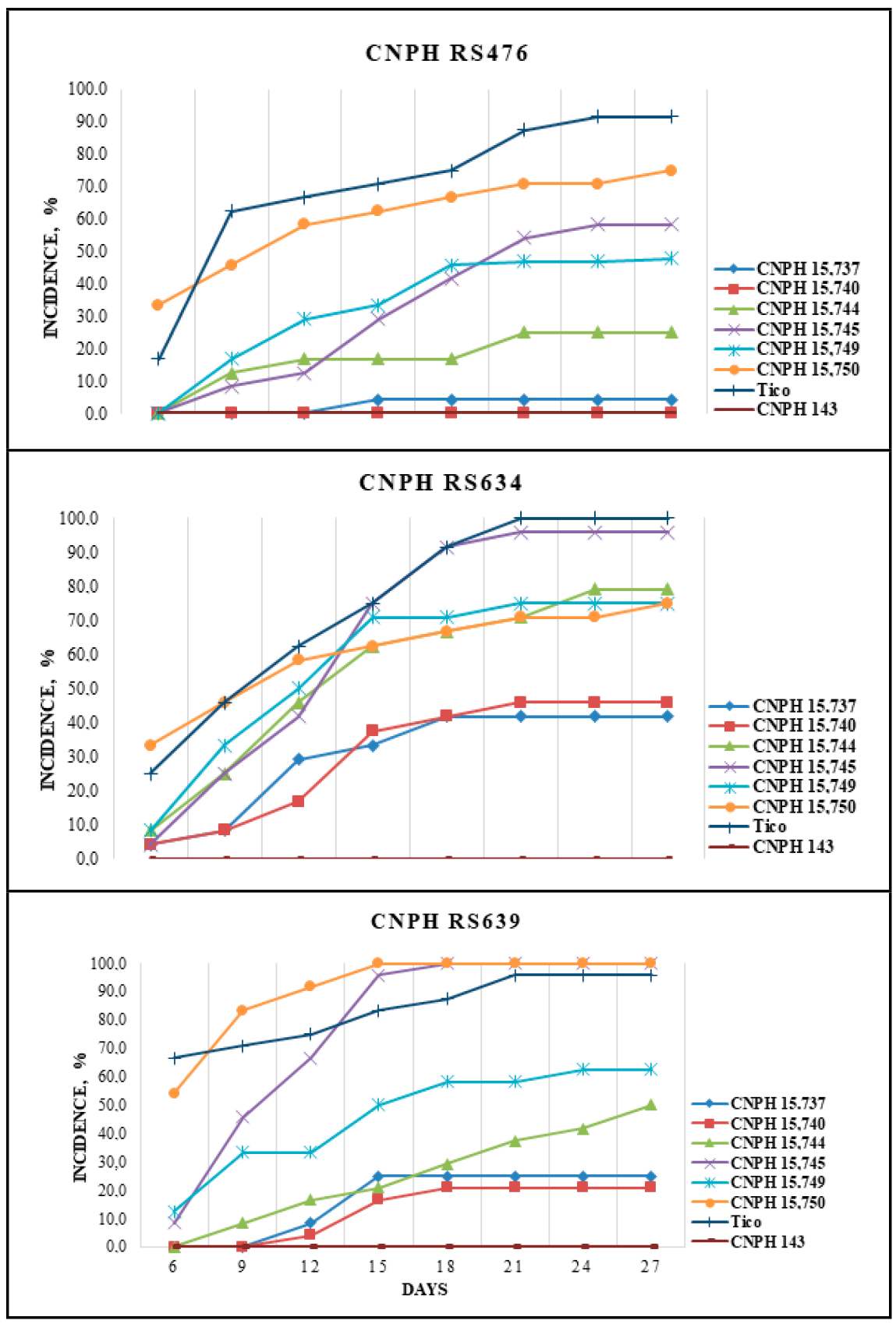

Figure 1. Plant wilt incidence in six Habanero pepper advanced inbred lines and susceptible (Tico) and resistant (CNPH 143) controls inoculated with three Ralstonia pseudosolanacearum isolates (CNPH RS476, CNPH RS634 and CNPH RS639). Brasília, Embrapa Hortaliças, 2019. significantly from the resistant control (CNPH 143) for CNPH RS634 isolate, for both AUDPC and severity, this inbred line presented a good level of resistance when compared to the susceptible control (Tico).

Different resistance levels of the evaluated inbred lines were observed in relation to $R$. pseudosolanacearum isolates. Inbred lines showed lower incidence of symptomatic plants for isolate CNPH RS476 in comparison to the highly virulent isolate $\mathrm{CNPH}$ RS634 (Figure 1). This fact reinforces the statement by Lopes et al. (2015) that the resistance to bacterial wilt is isolate specific rather than phylotype or biovar specific. This information should be taken into account in breeding programs aimed at resistance to bacterial wilt in different host plant species (Lopes \& Boiteux, 2004; Wicker et al., 2007).

Embrapa Hortaliças has been carrying out studies on identification and selection of resistance sources to R. pseudosolanacearum in Capsicum (Lopes \& Boiteux, 2004; Rossato et al., 2018) including the accessions CNPH 143 ('MC-4'), 'PBC 631', 'PBC 066', 'PBC 1347' and 'PBC 473' (Lopes \& Boiteux, 2004) and CNPH 3800 (Rossato et al., 2018). Cultivars of Habanero pepper BRS Nandaia and BRS Juruti, released previously by this breeding program, showed intermediate resistance to $R$. pseudosolanacearum (Ribeiro et al., 2015).

Among the inbred lines studied, CNPH 15.740 and CNPH 15.737 stood out for presenting high and moderate resistance levels, respectively, to the three $R$. pseudosolanacearum isolates tested. CNPH 15.744 also stood out for presenting moderate resistance to isolates CNPH RS476 and CNPH RS639.

\section{Reaction of inbred lines to Phytophthora capsici}

The viability of the Pcp 116 isolate and the experimental conditions were satisfactory, since high incidence and AUDPC values for wilting, damping off and necrosis were observed in the cultivar Ikeda, used as susceptible control (Figure 2, Table 3). Ribeiro $\&$ Bosland (2012) reported the high 
Table 2. Total area under the disease progress curve (AUDPC) and average values of severity of six Habanero pepper advanced inbred lines and in susceptibility (Tico) and resistance (CNPH 143) controls inoculated with three isolates of Ralstonia pseudosolanacearum (CNPH RS476, CNPH RS634 and CNPH RS639). Brasília, Embrapa Hortaliças, 2019.

\begin{tabular}{|c|c|c|c|c|c|c|}
\hline \multirow{2}{*}{ Genotypes } & \multicolumn{2}{|c|}{ CNPH RS476 } & \multicolumn{2}{|c|}{ CNPH RS634 } & \multicolumn{2}{|c|}{ CNPH RS639 } \\
\hline & AUDPC & Severity & AUDPC & Severity & AUDPC & Severity \\
\hline CNPH 15.737 & $0.6 \mathrm{Cb}^{1}$ & $1.1 \mathrm{BCa}$ & $5.9 \mathrm{Ca}$ & 1.6 DEa & $3.3 \mathrm{Cab}$ & 1.4 DEa \\
\hline CNPH 15.740 & $0 \mathrm{Cb}$ & $1.0 \mathrm{Cb}$ & $6.0 \mathrm{Ca}$ & $1.8 \mathrm{CDa}$ & $2.4 \mathrm{Cab}$ & $1.2 \mathrm{~Eb}$ \\
\hline CNPH 15.744 & $3.3 \mathrm{BCb}$ & $1.2 \mathrm{BCb}$ & $10.5 \mathrm{BCa}$ & $2.4 \mathrm{BCa}$ & $4.8 \mathrm{BCb}$ & $1.3 \mathrm{~Eb}$ \\
\hline CNPH 15.745 & $6.3 \mathrm{Bb}$ & $1.5 \mathrm{BCb}$ & $12.9 \mathrm{ABa}$ & $2.7 \mathrm{Ba}$ & $15.1 \mathrm{Aa}$ & $2.9 \mathrm{Ba}$ \\
\hline CNPH 15.749 & $6.3 \mathrm{Bb}$ & $1.8 \mathrm{ABb}$ & $11.1 \mathrm{Ba}$ & $2.7 \mathrm{Ba}$ & $8.8 \mathrm{Bab}$ & $2.0 \mathrm{CDb}$ \\
\hline CNPH 15.750 & $11.2 \mathrm{Ab}$ & $2.3 \mathrm{Ab}$ & 16.9 Аа & $4.3 \mathrm{Aa}$ & 17.0 Aa & 4.1 Aa \\
\hline Tico & $13.3 \mathrm{Aa}$ & $1.8 \mathrm{ABb}$ & $14.3 \mathrm{ABa}$ & $4.3 \mathrm{Aa}$ & 15.3 Aa & 4.5 Aa \\
\hline CNPH 143 & $0.0 \mathrm{Ca}$ & $1.0 \mathrm{Ca}$ & $0.0 \mathrm{Da}$ & $1.0 \mathrm{Ea}$ & $0.0 \mathrm{Ca}$ & $1.0 \mathrm{Ea}$ \\
\hline CV (\%) & 15.3 & 6.5 & 12.1 & 8.8 & 22.6 & 8.2 \\
\hline
\end{tabular}

${ }^{1}$ Average followed by same uppercase letters in the column and lowercase letters in the line does not differ significantly among the genotypes $(\mathrm{p}<0.05)$ by Tukey test.

Table 3. Total area under the disease progress curve (AUDPC) for damping off, plant wilt and stem base necrosis in six Habanero pepper advanced lines and in susceptible (Ikeda) and resistant (CNPH 148) controls inoculated with Phytophthora capsici isolate Pcp 116. Brasília, Embrapa Hortaliças, 2019.

\begin{tabular}{lrlrlr}
\hline Genotypes & Damping off & \multicolumn{1}{c}{ Wilting } & Necrosis \\
\hline CNPH 15.737 & $0.97 \mathrm{c}^{1}$ & $7.23 \mathrm{c}$ & $14.50 \mathrm{a}$ \\
CNPH 15.740 & $0.40 \mathrm{c}$ & $6.30 \mathrm{c}$ & $12.13 \mathrm{~b}$ \\
CNPH 15.744 & $2.53 \mathrm{~b}$ & $11.80 \mathrm{~b}$ & $15.10 \mathrm{a}$ \\
CNPH 15.745 & $0.80 \mathrm{c}$ & $8.17 \mathrm{bc}$ & $11.97 \mathrm{~b}$ \\
CNPH 15.749 & $0.00 \mathrm{c}$ & $1.17 \mathrm{de}$ & $11.10 \mathrm{~b}$ \\
CNPH 15.750 & $0.80 \mathrm{c}$ & $8.77 \mathrm{bc}$ & $11.93 \mathrm{~b}$ \\
Ikeda & $13.50 \mathrm{a}$ & $15.30 \mathrm{a}$ & $15.20 \mathrm{a}$ \\
CNPH 148 & $0.00 \mathrm{c}$ & $0.00 \mathrm{e}$ & $0.00 \mathrm{c}$ \\
\hline CV (\%) & 25.5 & 18.7 & 11.2 & \\
\hline
\end{tabular}

${ }^{1}$ Average followed by same lowercase letter in the column does not differ significantly among the genotypes $(\mathrm{p}<0.05)$ by Tukey test.

virulence of $P$. capsici race 18 based on pathogenicity reaction in pepper genotypes. The high virulence of this isolate was also verified in this study, considering that only the resistant control (CNPH 148) did not show symptomatic plants (Table 3 ).

All inbred lines evaluated, with exception of CNPH 15.744, showed higher levels of resistance to isolate Pcp116 than the susceptible control (Figure 2, Table 3). CNPH 15.749 presented the lowest AUDPC values for wilted plants, not differing significantly from the resistance control $\mathrm{CNPH}$ 148. For damping off, only the line
CNPH 15.744 was susceptible. CNPH 15.749; CNPH 15.740; CNPH 15.745 and CNPH 15.750 showed the lowest values of stem-base necrosis among the evaluated inbred lines, differing significantly from the susceptible control. However, the four inbred lines showed higher necrosis occurrence on the stem base in relation to the resistance control CNPH 148.

Infection by $P$. capsici may result in an expression of multiple disease symptoms, such as root rot, leaf wilt and stem necrosis, and each of these symptoms has a different resistance mechanism, requiring the presence of specific resistance genes to each one (Reeves et al., 2013; Barchenger et al., 2017). Therefore, the occurrence of stem base necrosis in the studied inbred lines may be related to the presence of genes that differ from those that determine partial resistance observed in most of the studied inbred lines, taking into consideration wilting and damping off symptoms (Figure 2, Table 3).

Steiner \& Bosland (2008) report that breeding for resistance to $P$. capsici in peppers is difficult and complex mainly due to the quantitative nature of inheritance (Naresh et al., 2019). Naresh et al. (2019) highlight that the CM334 resistance (from the one which $\mathrm{CNPH}$ 148 was derived) to several $P$. capsici isolates is polygenic with additive and epistatic effect, so little success has been obtained in breeding programs using this genotype. The partial resistance of Habanero pepper lines in this study may be related to this complex effect, but further studies are necessary for its elucidation.

CNPH 15.749 stood out for presenting higher levels of resistance than other evaluated inbred lines and susceptible control, differing from resistance control CNPH 148 only in relation to the occurrence of stembase necrosis. CNPH 15.740 showed moderate resistance to the $P$. capsici isolate.

The use of resistant cultivars 


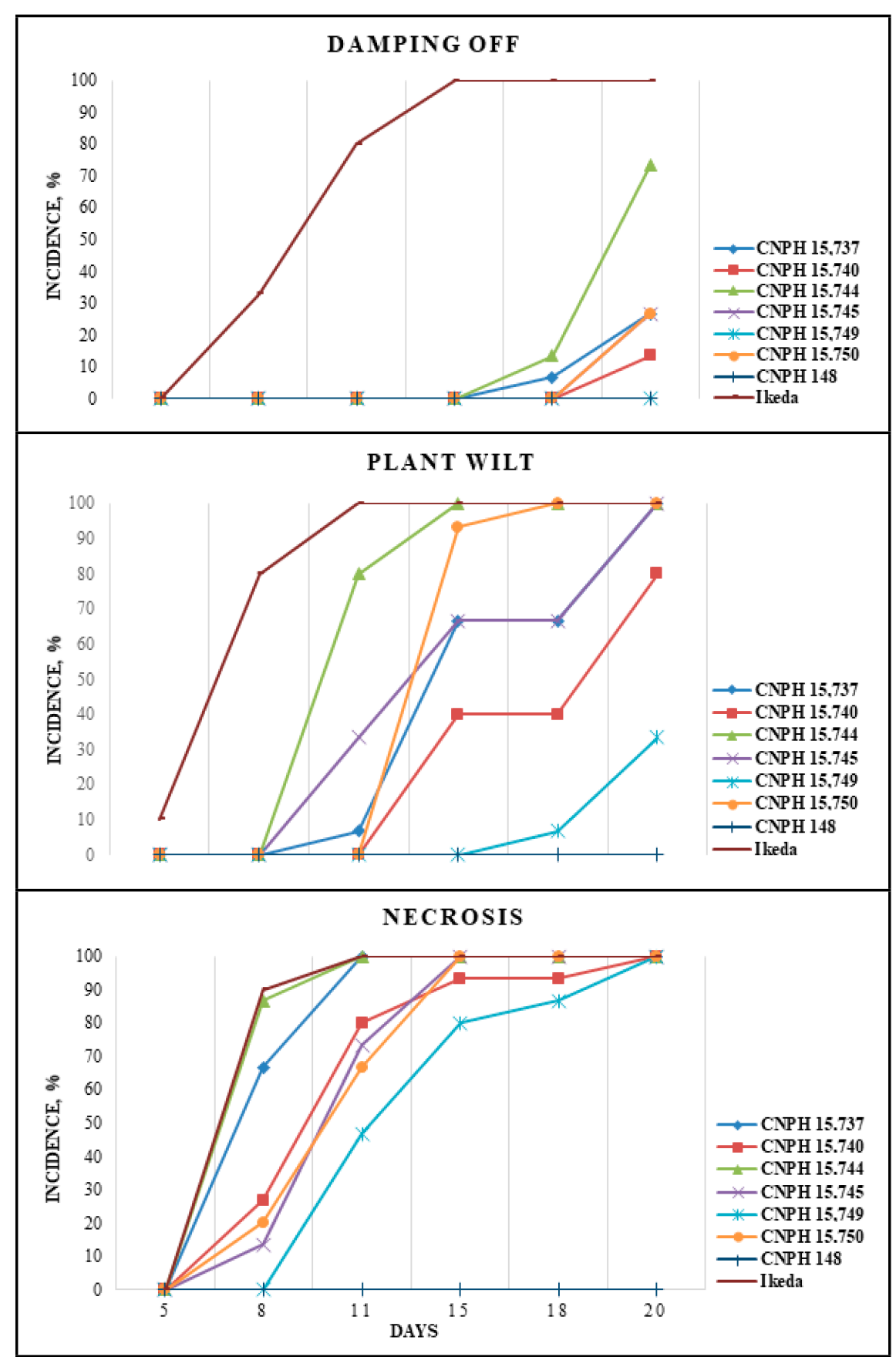

Figure 2. Damping off, plant wilt and stem base necrosis incidence in six Habanero pepper advanced lines and in susceptible (Ikeda) and resistant (CNPH 148) controls inoculated with Phytophthora capsici isolate Pcp 116. Brasília, Embrapa Hortaliças, 2019.

is the most suitable way to control diseases due to its low cost, high efficiency and reduced environmental impact, especially when compared to other strategies that aim to control the pathogen after its establishment (Rossato et al., 2018).

This study identified Habanero pepper inbred lines with high and intermediate levels of resistance to $R$. pseudosolanacearum and to $P$. capsici.
CNPH 15.737 and CNPH 15.740 were highly resistant to RP isolates and CNPH 15.749 presented considerable resistance $P$. capsici isolate Pcp 116. CNPH 15.740 stands out presenting a high level of resistance to RP isolates and intermediate resistance to $\mathrm{PC}$; this line also presents desirable agronomic traits, such as high pungency, attractive flavor and aroma, intermediate plant architecture, important nutraceutical compounds and high yield. The information obtained in this study will serve as complementary data to SNPC/MAPA technical forms for the registration and protection of cultivars in Brazil (National Cultivation Protection Service/Ministry of Agriculture, Livestock and Food Supply and RNC/ MAPA - National Register of Cultivars).

\section{REFERENCES}

BARCHENGER, DW; LAMOUR, KH; SHEU, Z; SHRESTHA, S; KUMAR, S; LIN, S; BURLAKOTI, R; BOSLAND, PW. 2017. Intra- and intergenomic variation of ploidy and clonality characterize Phytophthora capsici on Capsicum sp. in Taiwan. Mycological Progress 16: 955-963.

BARCHENGER, DW; LAMOUR, KH; BOSLAND, PW. 2018. Challenges and strategies for breeding resistance in Capsicum annuum to the multifarious pathogen, Phytophthora capsici. Frontiers in Plant Science 9: 1-16.

BOSLAND, PW; COON, D. 2015. 'NuMex Trick-or-Treat', a no-heat Habanero pepper. HortScience 50: 1739-1740.

CASTRO-CONCHA, LA; TUYUB-CHE, J; MOO-MUKUL, A; VAZQUEZ-FLOTA, FA; MIRANDA-HAM, ML. 2014. Antioxidant capacity and total phenolic content in fruit tissues from accessions of Capsicum chinense Jacq. (Habanero pepper) at different stages of ripening. The Scientific World Journal 195: $1-5$.

COELHO NETTO, RA; PEREIRA, BG; NODA, H; BOHER, B. 2004. Murcha bacteriana no Estado do Amazonas, Brasil. Fitopatologia Brasileira 29: 21-27.

DUNN, AR; LANGE, HW; SMART, CD. 2014. Evaluation of commercial bell pepper cultivars for resistance to phytophthora blight (Phytophthora capsici). Plant health progress 15: 19-24.

FERREIRA, DF. 2011. Sisvar: a computer statistical analysis system. Ciência e Agrotecnologia 35: 1039-1042.

GILARDI, G; BAUDINO, M; MOIZIO, M; PUGLIESE, M; GARIBALDI, A; GULLINO, ML. 2013. Integrated management of Phytophthora capsici on bell pepper by combining grafting and compost treatment. Crop Protection 53: 13-19.

GRANKE, LL; QUESADA-OCAMPO, L; LAMOUR, KH; HAUSBECK, MK. 2012. Advances in research on Phytophthora capsici on vegetable crops in the United States. Plant Disease 96: 1588-1600.

HONG, JC; NORMAN, DJ; REED, DL; MOMOL, MT; JONES, JB. 2012. Diversity among Ralstonia solanacearum strains isolated from the southeastern United States. Phytopathology 102: 924-936.

JARQUE, C; BERA, A. 1987. A test for normality of observations and regression residuals. 
International Statistical Review 55: 163-172.

LEBEAU, A; DAUNAY, MC; FRARY, A; PALLOIX, A; WANG, JF; DINTINGER, J; CHIROLEU, F; WICKER, E; PRIOR, P. 2011. Bacterial wilt resistance in tomato, pepper, and eggplant: Genetic resources respond to diverse strains in the Ralstonia solanacearum species complex. Phytopathology 101: 154-165.

LOPES, CA; BOITEUX, LS. 2004. Biovarspecific and broad-spectrum sources of resistance to bacterial wilt (Ralstonia solanacearum) in Capsicum. Crop Breeding and Applied Biotechnology 4: 350-355.

LOPES, CA; BOITEUX, LS; ESCHEMBACK, V. 2015. Eficácia relativa de porta-enxertos comerciais de tomateiro no controle da murcha-bacteriana. Horticultura Brasileira 33: $125-130$.

MADEIRA, NR; AMARO, GB; MELO, RAC; RIBEIRO, CSC; REIFSCHNEIDER, FJB. 2016. Compatibilidade de porta-enxertos para pimentão em cultivo protegido. Horticultura Brasileira 34: 470-474.

NASS, LL; SOUZA, KRR; RIBEIRO, CSC; REIFSCHNEIDER, FJB. 2015. Synthesis of a base population of Habanero pepper. Horticultura Brasileira 33: 530-532.

NARESH, P; MEENU, K; ACHARYA, GC; REDDY, AC; LAKSHMANA, DCR. 2019. Genetics and molecular markers for resistance to major soil borne pathogens in chilli (Capsicum annuum L.). Research Journal of Biotechnology 14: 101-105.

PETRY, R; PAZ-LIMA, ML; BOITEUX, LS; CAFÉ-FILHO, AC; REIS, A. 2016. Reaction of Solanum (section Lycopersicon) germplasm to Phytophthora capsici. European Journal of Plant Pathology 148: 481-489.

PINHEIRO, JB; REIFSCHNEIDER, FJB; PEREIRA, RB; MOITA, AW. 2014. Reação de genótipos de Capsicum ao nematoide das galha. Horticultura Brasileira 32: 371-375.

REEVES, G; MONROY-BARBOSA, A; BOSLAND, PW. 2013. A Novel Capsicum gene inhibits host-specific disease resistance to Phytophthora capsici. Phytopathology 103: 472-478.

RIBEIRO, CSC; BOSLAND, PW. 2012. Physiological race characterization of Phytophthora capsici isolates from several host plant species in Brazil using New Mexico recombinant inbred lines of Capsicum annuum at two inoculum levels. Journal of the American Society for Horticultural Science 137: 421-426.

RIBEIRO, CSC; SOUZA, KRR; CARVALHO, SIC; REIFSCHNEIDER, FJB. 2015. BRS Juruti: the first Brazilian habanero-type hot pepper cultivar. Horticultura Brasileira 33: 527-529.

ROSSATO, M; SANTIAGO, TR; LOPES, CA. 2018. Reaction of Capsicum peppers commercialized in the Federal District to bacterial wilt. Horticultura Brasileira 36: 173-177.

SÁNCHEZ-CHÁVEZ, E; SILVA-ROJAS, HV; LEYVA-MIR, G; VILLARREALGUERRERO, F; JIMÉNEZ-CASTRO, JA; MOLINA-GAYOSSO, E; GARDEA-BÉJAR, AA; ÁVILA-QUEZADA, GD. 2017. An effective strategy to reduce the incidence of Phytophthora root and crown rot in bell pepper. Interciencia 42: 229-235.

SHANER, G; FINNEY, RE. 1977. The effect of nitrogen fertilization on the expression of slow-mildewing resistance in knox wheat. Phytopathology 67: 1051-1056.

STEINER, OSR; BOSLAND, PW. 2008. Recombinant inbred line differential identifies race-specific resistance to Phytophthora root rot in Capsicum annuum. Phytopathology 98: 867-870.

STEEL, RGD; TORRIE, JH; DICKEY, DA. 1997. Principles and procedures of statistics: a biometrical approach. 3.ed. New York: McGraw Hill Book. 666p.

TEODORO, AFP; ALVES, RBN; RIBEIRO, LB; REIS, K; REIFSCHNEIDER, FJB; FONSECA, MEN; SILVA, JP; AGOSTINICOSTA, TS. 2013. Vitamin C content in Habanero pepper accessions (Capsicum chinense). Horticultura Brasileira 31: 59-62.

VÁZQUEZ, PV; CORTEZ, MCN. 2018. Use of organic alternatives in the production system of habanero pepper (Capsicum chinense Jacq.) under greenhouse conditions. African Journal of Agricultural Research 13: 1091-1094.

WICKER, E; GRASSART, L; CORANSONBEAUDU, R; MIAN, D; GUILBAUD, C; FEGAN, M. 2007. Ralstonia solanacearum strains from Martinique (French west indies) exhibiting a new pathogenic potential. Applied and Environmental Microbiology 73: 67906801.

WINSTEAD, NN; KELMAN, A. 1952. Inoculation techniques for evaluation of resistance to Pseudomonas solanacearum. Phytopathology 42: 628-634. 